\title{
Indigenous and introduced species of the Bemisia tabaci complex in sweet potato crops from Argentina
}

\author{
Alemandri, V.; J.A. Martino, L. Di Feo and G. Truol.
}

\begin{abstract}
SUMMARY
Sweet potato (Ipomoea batatas (L.) Lam) is one of the most important crops worldwide. Recently, the appearance of severe viral symptoms has been observed in sweet potato crops in the pampas region of Argentina and both begomovirus and crinivirus, exclusively transmitted by whiteflies, have been identified. The aim of this study was to identify $B$. tabaci species from sweet potato crops in Colonia Caroya by analysing mitochondrial cytochrome $\mathrm{C}$ oxidase subunit I (mtCOI) sequences. Two previously described haplotypes were identified: New World2 (indigenous species) and MEAM1 (introduced species). The results indicate the presence of both species, which are potential vectors of begomovirus and crinivirus in Argentina.
\end{abstract}

Keywords: whitefly, mitochondrial cytochrome c oxidase subunit I, Ipomoea batatas

Alemandri, V.; J.A. Martino, L. Di Feo y G. Truol, 2014. Especies nativas e introducidas del complejo Bemisia tabaci en cultivos de batata de Argentina. Agriscientia 31 (2): 103-107

\section{RESUMEN}

La batata (Ipomoea batatas (L.) Lam) es uno de los cultivos más importantes en el mundo. Recientemente se observó una severa sintomatología viral en cultivos de la región pampeana argentina, en la que están identificados begomovirus y crinivirus, ambos transmitidos exclusivamente por mosca blanca. El objetivo de este estudio fue identificar las especies de B. tabaci en cultivos de batata en Colonia Caroya, mediante el análisis de secuencias mitocondriales de la citocromo oxidasa subunidad I (mtCOI). Se identificaron dos haplotipos (especies crípticas) ya descriptos en el mundo: New World2 (especie nativa) y MEAM1 (especie introducida). Los resultados indican la presencia de ambas especies, las cuales son potenciales vectores de begomovirus y crinivirus en batata en Argentina.

Palabras clave: mosca blanca, citocromo oxidasa subunidad I, Ipomoea batatas 
V. Alemandri, J.A. Martino, L. Di Feo and G. Truol. Instituto de Patología Vegetal - Centro de Investigaciones Agropecuarias - Instituto Nacional de Tecnología Agropecuaria (IPAVE-CIAP-INTA). Camino 60 Cuadras Km 5 1⁄2, X5020ICA. Córdoba, Argentina. Correspondence to: alemandri.vanina@inta.gob.ar

Bemisia tabaci (Gennadius) (Hemiptera: Aleyrodidae) is a cryptic species complex (Dinsdale et al., 2010; De Barro et al., 2011) that causes annual economic damages ranging from several hundred millions to billions of dollars worldwide (Oliveira et al., 2001). B. tabaci is a vector of emerging plant viruses worldwide, including the genera begomovirus and crinivirus (Navas-Castillo et al., 2011).

Until 2010, B. tabaci was considered a complex composed of at least 24 distinct putative species (hereon species) (Dinsdale et al., 2010; De Barro et al., 2011). Recently, at least 15 new species have been reported (Hu et al., 2011; Alemandri et al., 2012; Chowda-Reddy et al., 2012; Parrella et al., 2012; Firdaus et al., 2013; Esterhuizen et al., 2013).

Middle East-Asia Minor 1 (hereafter MEAM1 and commonly referred to as the B biotype in the literature) is known worldwide as one of the most invasive and destructive species in the complex (Perring, 2001). In Argentina, MEAM1 was first detected on horticultural crops, weeds and cotton samples (Viscarret et al., 2003). Furthermore, recent studies have demonstrated the presence of an indigenous species belonging to the $B$. tabaci cryptic species complex in Argentina, a new species affecting soybean and bean crops named New World2 (Alemandri et al., 2012).

Sweet potato (Ipomoea batatas (L.) Lam) is one of the most important crops worldwide, with great potential not only for human consumption but also for animal feeding and industrial use (BovellBenjamin, 2007). Argentina produced 340,105 metric tons in 2009 (USDA Economics and System, 2011), mainly in the pampas region (Buenos Aires, Córdoba and Santa $\mathrm{Fe}$ provinces). Recently, severe viral symptoms have been observed in this area. Previous studies suggest that more than one etiologic agent is involved in this new viral disease, including both begomovirus and crinivirus exclusively transmitted by whiteflies (Di Feo et al., 2000; Rodríguez Pardina et al., 2012). Although there are records of presence of whiteflies, the species of $B$. tabaci present in this area have not been identified. The aim of this work was to identify species of $B$. tabaci present in sweet potato crops from Colonia Caroya in Argentina by analysing mitochondrial cytochrome c oxidase subunit I (mtCOI) sequences.

Adult whiteflies (Bemisia tabaci) were collected from five sweet potato fields in Colonia Caroya, Colón department, Córdoba province $\left(31^{\circ} 02^{\prime}\right.$ $02^{\prime \prime} \mathrm{S}, 64^{\circ} 04^{\prime} 46^{\prime \prime} \mathrm{W}$ ), in the pampas region, an important sweet potato growing area in Argentina. Live adult whiteflies were collected and placed in tubes containing $100 \%$ ethanol and maintained at $4^{\circ} \mathrm{C}$ until DNA extraction.

Whitefly individuals were sexed, and DNA was extracted from females, following the protocol of De Barro \& Driver (1997) and Truol et al. (2003). A total of 10 females were analysed. Females were individually homogenized in $60 \mu \mathrm{l}$ filtered lysis buffer (10 mM Tris-HCl, pH 8, 1 mM EDTA, 0.3\% Triton X-100, $60 \mu \mathrm{g} / \mathrm{ml}$ proteinase $\mathrm{K}$ ) using 1.5 $\mathrm{ml}$ microcentrifuge tubes. The homogenate was incubated at $65^{\circ} \mathrm{C}$ for $15 \mathrm{~min}$ and at $98^{\circ} \mathrm{C}$ for $6 \mathrm{~min}$. Then, it was centrifuged at $9600 \mathrm{rpm}$ for $1 \mathrm{~min}$ and maintained at $-20{ }^{\circ} \mathrm{C}$. The primers C1-J-2195 and L2-N-3014 were used for amplification (Simon et al., 1994; Frohlich et al., 1999). PCR reactions were carried out in a final volume of $25 \mu$ containing $1 \mathrm{U}$ Taq DNA polymerase (Invitrogen), $2.5 \mathrm{mM} \mathrm{MgCl}_{2}$, $0.20 \mathrm{mM}$ dNTP, $0.6 \mu \mathrm{M}$ of each primer and $2 \mu \mathrm{l}$ of DNA. The reactions were performed with a thermal cycler programmed for one cycle of 2 min at $94^{\circ} \mathrm{C}$, followed by 30 cycles $\left(1 \mathrm{~min}\right.$ at $94^{\circ} \mathrm{C}, 1 \mathrm{~min}$ at 52 ${ }^{\circ} \mathrm{C}$ and 1 min at $72{ }^{\circ} \mathrm{C}$ ) and a final 5 -min extension at $72{ }^{\circ} \mathrm{C}$. Amplification products were analysed by $1.5 \%$ agarose gel electrophoresis. The amplified products of about 800 base pairs were purified using illustra MicroSpin S-200 HR Columns (GE Healthcare, UK) and sequenced in both directions with the amplification primers using an ABI 3130XL (Applied Biosystems) automated sequencer.

A total of 438 sequences were used to identify unique haplotypes of $B$. tabaci $\mathrm{mtCO}$ sequences, 
which included 10 from our own whitefly collection and 428 unique haplotypes retrieved from GenBank. The latter comprised the sequences used in Firdaus et al. (2013) (which in turn included nine outgroups), newly proposed groups (ChowdaReddy et al., 2012; Parrella et al., 2012; Esterhuizen et al., 2013) and the New World2 sequences recently detected in Brazil (Marubayashi et al., 2012). All the mtCOI sequences were 657 bases in length and were aligned using the CLUSTAL W Multiple alignment procedure (Thompson et al., 1994) implemented in the BIOEDIT software, version 7.0.4 (Hall, 1999). A total of 428 unique $B$. tabaci $\mathrm{mtCO}$ sequence haplotypes were identified from the analysis of 438 sequences using DnaSP v5 (Librado \& Rozas, 2009).

Of the $10 \mathrm{mtCO}$ sequences generated in this study, two haplotypes were identified (Hap-1 and Hap-2) that belong to two species of the B. tabaci complex in sweet potato crops in Argentina. Hap-1 was identical to a New World2 haplotype (JF901844) previously described in bean and soybean crops in Argentina (Alemandri et al., 2012). Hap-2 was identical to a MEAM1 haplotype (GU086344) previously described in USA, Dominican Republic, Trinidad and Tobago, Brazil, Spain, Italy and South Africa (Firdaus et al., 2013). Because the sequences generated in this study were not new haplotypes, phylogenetic analyses or pairwise comparison of genetic distances were not performed. Haplotypes previously described and identical to the sequences presented here were correctly identified using the new criteria proposed for B. tabaci (Alemandri et al., 2012; Firdaus et al., 2013). These two whitefly species were found to co-occur in three fields (Table 1).

The analysis of $\mathrm{mtCO}$ supports the existence of two species of the $B$. tabaci complex in sweet potato fields in Argentina: an indigenous species belonging to the New World2 putative species, and an introduced species belonging to the MEAM1 putative species. This is the first report of MEAM1 in sweet potato in Argentina, and is in agreement with a previous study reporting the presence of MEAM1 in sweet potato in Cuba using information on the mtCOI gene (Muniz et al., 2011). Furthermore, several species, Asia II 1 (Liu et al., 2010), Asia II 6 (Ueda et al., 2009), Asia II 9, Asia II 10 (Hu et al., 2011), Indian Ocean (Delatte et al., 2005), Uganda (Maruthi et al., 2004), Mediterranean (De la Rua et al., 2006) and New World (Muniz et al., 2011) were found in 1 . batatas in other countries. To the best of our knowledge, this is the first report of New World2 in sweet potato from Argentina.

On the other hand, the results presented here suggest that New World2 and MEAM1 cooccurred in sweet potato under field conditions (Table 1). Similar events have been noted in Brazil, where specimens of the MEAM1 and New World2 species were found colonizing a single plant of Glycine maxima, or the same plot on Euphorbia heterophylla (Marubayashi et al., 2012). Previous studies indicate that the development of a hybrid whitefly between two species such as MEAM1 and Mediterranean is unlikely (Sun et al., 2011; McKenzie et al., 2012). There are no records of the development of a hybrid between New World2 and MEAM1.

The identification of the two species of the $B$. tabaci complex in sweet potato crops suggests that they would be the insect vectors responsible for sweet potato begomovirus and crinivirus transmission in Argentina. The present results highlight the need to further explore the diversity of the $B$. tabaci species present in sweet potato crops in the pampas region, as well as to conduct virus transmission experiments.

Table 1. Populations of Bemisia tabaci sampled in sweet potato crops in Argentina and identified by sequencing of the mtCOI gene.

\begin{tabular}{|c|c|c|c|c|c|c|c|}
\hline $\begin{array}{c}\mathbf{N}^{\circ} \\
\text { Field } \\
\end{array}$ & Host plant & Province & $\begin{array}{c}\text { Collection } \\
\text { date }\end{array}$ & $\begin{array}{c}\text { Sample } \\
\text { code }\end{array}$ & Haplotype & Putative species & $\begin{array}{c}\text { GenBank } \\
\text { Accession } \\
\text { number }\end{array}$ \\
\hline 1 & Ipomoea batatas & Córdoba & 2012 & Bat-1 & Hap-1 & New World2 & KM100350 \\
\hline 1 & Ipomoea batatas & Córdoba & 2012 & Bat-2 & Hap-1 & New World2 & KM100351 \\
\hline 2 & Ipomoea batatas & Córdoba & 2012 & Bat-3 & Hap-1 & New World2 & KM100352 \\
\hline 2 & Ipomoea batatas & Córdoba & 2012 & Bat-4 & Нар-2 & MEAM1 & KM100358 \\
\hline 3 & Ipomoea batatas & Córdoba & 2012 & Bat-5 & Hap-1 & New World2 & KM100353 \\
\hline 3 & Ipomoea batatas & Córdoba & 2012 & Bat-6 & Hap-1 & New World2 & KM100354 \\
\hline 4 & Ipomoea batatas & Córdoba & 2012 & Bat-7 & Hap-2 & MEAM1 & KM100359 \\
\hline 4 & Ipomoea batatas & Córdoba & 2012 & Bat-8 & Hap-1 & New World2 & KM100355 \\
\hline 5 & Ipomoea batatas & Córdoba & 2012 & Bat-9 & Hap-1 & New World2 & KM100356 \\
\hline 5 & Ipomoea batatas & Córdoba & 2012 & Bat-10 & Hap-2 & MEAM1 & KM100357 \\
\hline
\end{tabular}




\section{ACKNOWLEDGMENTS}

We would like to thank INTA -Instituto Nacional de Tecnología Agropecuaria- and Fundación ArgenINTA for financial support.

\section{REFERENCES}

Alemandri, V.; P. De Barro, N. Bejerman, E.B. ArgüelloCaro, A.D. Dumón, M.F. Mattio, M.S. Rodriguez and G. Truol, 2012. Species within the Bemisia tabaci (Hemiptera: Aleyrodidae) complex in soybean and bean crops in Argentina. J. Econ. Entomol. 105: 48-53.

Bovell-Benjamin, A.C., 2007. Sweet potato: a review of its past, present, and future role in human nutrition. Adv. Food. Nutr. Res. 52: 1-59.

Chowda-Reddy, R.V.; M. Kirankumar, S.E. Seal, V. Muniyappa, G.B. Valand, M.R. Govindappa and J. Colvin, 2012. Bemisia tabaci phylogenetic groups in India and the relative transmission efficacy of Tomato leaf curl Bangalore virus by an indigenous and an exotic population. J. Integr. Agric. 11: 235-248.

De Barro, P.J. and F. Driver, 1997. Use of RAPD-PCR to distinguish the $\mathrm{B}$ biotype from other biotypes of Bemisia tabaci (Gennadius) (Hemiptera: Aleyrodidae). Aust. J. Entomol. 36: 149-152.

De Barro, P.J.; S.S. Liu, L.M. Boykin and A.B. Dinsdale, 2011. Bemisia tabaci: a statement of species status. Annu. Rev. Entomol. 56: 1-19.

De La Rua, P.; J.L. Cenis, B. Simon, D. Cifuentes and C. Martinez-Mora, 2006. New insights into the mitochondrial phylogeny of the whitefly Bemisia tabaci (Hemiptera: Aleyrodidae) in the Mediterranean Basin. J. Zoolog. Syst. Evol. Res. 44: 25-33.

Delatte, H.; B. Reynaud, M. Granier, L. Thornary, J.M. Lett, R. Goldbach and M. Peterschmitt, 2005. A new silverleaf-inducing biotype Ms of Bemisia tabaci (Hemiptera: Aleyrodidae), indigenous to the islands of the south west Indian Ocean. Bull. Entomol. Res. 95(1): 29-35.

Di Feo, L.; S.F. Nome, E. Biderbost, S. Fuentes and L. Salazar, 2000. Etiology of Sweet Potato Chlorotic Dwarf Disease in Argentina. Plant Dis. 84: 35-39.

Dinsdale, A.; L. Cook, C. Riginos, Y.M. Buckley and P. De Barro, 2010. Refined Global Analysis of Bemisia tabaci (Hemiptera: Sternorrhyncha: Aleyrodoidea: Aleyrodidae) Mitochondrial Cytochrome Oxidase 1 to Identify Species Level Genetic Boundaries. Ann. Entomol. Soc. Am. 103: 196-208.

Esterhuizen, L.L.; K.G. Mabasa, S.W. van Heerden, H. Czosnek, J.K. Brown, H. van Heerden and M.E.C. Rey, 2013. Genetic identification of members of the Bemisia tabaci cryptic species complex from South
Africa reveals native and introduced haplotypes. J. Appl. Entomol. 137: 122-135.

Firdaus, S.; B. Vosman, N. Hidayati, E.D.J. Supena, R.G.F. Visser and A.W. van Heusden, 2013. The Bemisia tabaci species complex: Additions from different parts of the world. Insect Sci. 20(6): 723-733.

Frohlich, D.; I. Torres-Jerez, I.D. Bedford, P.G. Markham and J.K. Brown, 1999. A phylogeographic analysis of the Bemisia tabaci species complex based on mitochondrial DNA markers. Mol. Ecol. 8: 1593-1602.

Hall, T.A., 1999. BIOEDIT: a user-friendly biological sequence alignment editor and analysis program for windows 95/98/NT. Nucleic Acids Symposium Series 41: $95-98$.

Hu, J.; P. De Barro, H. Zhao, J. Wang, F. Nardi and S.S. Liu, 2011. An Extensive Field Survey Combined with a Phylogenetic Analysis Reveals Rapid and Widespread Invasion of Two Alien Whiteflies in China. PLoS ONE 6(1): e16061. doi:10.1371/journal.pone.0016061.

Librado, P. and J. Rozas, 2009. DnaSP v5: a software for comprehensive analysis of DNA polymorphic data. Bioinformatics 25: 1451-1452.

Liu, J.; M. Li, J.M. Li, C.J. Huang, X.P. Zhou, F.C. Xu and S.S. Liu, 2010. Viral infection of tobacco plants improves performance of Bemisia tabaci but more so for an invasive than for an indigenous biotype of the whitefly. J Zhejiang Univ. Sci. B. 11, 30-40. doi: 10.1631/jzus.B0900213.

Marubayashi, J.M.; V.A. Yuki, K.C.G. Rocha, T. Mituti, F.M. Pelegrinotti, F.Z. Ferreira, M.F. Moura, J. NavasCastillo, E. Moriones, M.A. Pavan and R. KrauseSakate, 2012. At least two indigenous species of the Bemisia tabaci complex are present in Brazil. J. Appl. Entomol. 137: 113-121.

Maruthi, M.N.; J. Colvin, R.M. Thwaites, G.K. Banks, G. Gibson and S.E. Seal, 2004. Reproductive incompatibility and cytochrome oxidase I gene sequence variability amongst host-adapted and geographically separate Bemisia tabaci populations (Hemiptera: Aleyrodidae). Systematic Entomology 29: 560-568.

McKenzie, C.L.; J.A. Bethke, F.J. Byrne, J.R. Chamberlin, T.J. Dennehy, A.M. Dickey, D. Gilrein, P.M. Hall, S. Ludwig, R.D. Oetting, L.S. Osborne, L. Schmale and R.G. Jr. Shatters, 2012. Distribution of Bemisia tabaci (Hemiptera: Aleyrodidae) biotypes in North America after the $Q$ invasion. J. Econ. Entomol. 105: 753-766.

Muniz, Y.; M. Granier, C. Caruth, P. Umaharan, C. Marchal, C. Pavis, E. Wicker, Y. Martinez and M. Peterschmitt, 2011. Extensive Settlement of the Invasive MEAM1 population of Bemisia tabaci (Hemiptera: Aleyrodidae) in the Caribbean and Rare Detection of Indigenous Populations. Environ. Entomol. 40(5): 989-998.

Navas-Castillo, J.; E. Fiallo-Olivé and S. Sánchez- 
Campos, 2011. Emerging Virus Diseases Transmitted by Whiteflies. Annu. Rev. Phytopathol. 49: 219-248.

Oliveira, M.R.V.; T.J. Henneberry and P. Anderson, 2001. History, current status, and collaborative research projects for Bemisia tabaci. Crop Prot. 20: 709-723.

Parrella, G.; L. Scassillo and M. Giorgini, 2012. Evidence for a new genetic variant in the Bemisia tabaci species complex and the prevalence of the biotype $Q$ in southern Italy. J. Pest Sci. 85: 227-238.

Perring, T.M., 2001. The Bemisia tabaci species complex. Crop Prot. 20: 725-737.

Rodríguez Pardina, P.; A. Luque, C. Nome, E. López Colomba, S. Fuentes Delgado and L. Di Feo, 2012. First report of Sweet potato leaf curl virus infecting sweet potato in Argentina. Australas. Plant Dis. Notes 7(1): 157-160.

Simon, C.; F. Frati; A. Beckenbach, B. Crespi, H. Liu and P. Flook, 1994. Evolution, weighting and phylogenetic utility of mitochondrial gene sequences and a compilation of conserved polymerase chain reaction primers. Ann. Entomol. Soc. Am. 87: 651-701.

Sun, D.B.; J. Xu, J.B. Luan and S.S. Liu, 2011. Reproductive incompatibility between the $\mathrm{B}$ and $Q$ biotypes of the whitefly Bemisia tabaci in China: genetic and behavioral evidence. Bull. Entomol. Res. 101: 211-220.

Thompson, J.D.; D.G. Higgins and T.J. Gibson, 1994.
CLUSTAL W: improving the sensitivity of progressive multiple sequence alignment through sequence weighting, position-specific gap penalties and weight matrix choice. Nucleic Acids Research 22(22): 46734680.

Truol, G.; W.N. Martins Lago, P.R. Queiroz, L.H. Correa Lima, M.R. Vilarinho de Olivera, I.G. Laguna, W.M. Paiva e A.M. Rodriguez Almeida, 2003. Variabilidade Genética determinada por RAPD-PCR de Populacoes de Bemisia tabaci provenientes de Brasil, Argentina e Paraguai, Brasília, Embrapa Recursos Genéticos e Biotecnologia, Boletim de pesquisa e desenvolvimento 54: 1-19.

Ueda, S.; T. Kitamura, K. Kijima, K.I. Honda and K. Kanmiya, 2009. Distribution and molecular characterization of distinct Asian populations of Bemisia tabaci (Hemiptera: Aleyrodidae) in Japan. J. Appl. Entomol. 133: 355-366.

USDA, Economics and S.a.M.I. System, 2011. Sweet potato statistics, Albert R Mann Library, Cornell University.

Viscarret, M.M.; I. Torres-Jerez, E. Agostini De Manero, S.N. López, E.E. Botto and J.K. Brown, 2003. Mitochondrial DNA evidence for a distinct New World group of Bemisia tabaci (Gennadius) (Hemiptera: Aleyrodidae) indigenous to Argentina and Bolivia, and presence of the Old World B biotype in Argentina. Ann. Entomol. Soc. Am. 96: 65-72. 